\title{
Right Atrial Thrombus in Transient in a COVID-19 Patient: Clinical Echocardiographic Features-Case Report and Literature Review
}

\author{
Cheikh A. Abool Maaly ${ }^{1} \cdot$ Jassim Al Suwaidi $^{1,2} \cdot$ Mohamad Yahya Khatib $^{3} \cdot$ Hakam Alzaeem $^{1}$
}

Accepted: 1 October 2020 / Published online: 8 October 2020

(C) The Author(s) 2020

\begin{abstract}
A 54-year-old male is admitted with COVID-19 pneumonia and received prophylactic anticoagulation. On day 8 , the patient rapidly deteriorated requiring urgent endotracheal intubation. Transthoracic echocardiography revealed large right atrial thrombus in transient, resulting in pulmonary embolism and severe RV failure; fibrinolytic therapy was not effective and the patient passed away.
\end{abstract}

Keywords COVID-19 $\cdot$ Right atrial thrombus $\cdot$ Pulmonary embolism $\cdot$ Right heart failure

\section{Case Presentation}

A 54-year-old male presented to the emergency department with history of fever and nonproductive cough for 1-day duration; on presentation, he was afebrile, and the patient's heart rate is 88 beats/min, respiratory rate $16 / \mathrm{min}$, and blood pressure was 154 / $96 \mathrm{mmHg}$. The patient had normal arterial oxygen saturation $\left(\mathrm{SaO}_{2}\right) 98 \%$ on room air. Physical examination demonstrated coarse crackles in the bilateral lower lung fields. Laboratory results throughout hospitalization are shown in Table 1.

The electrocardiogram on admission showed normal sinus rhythm; chest X-ray showed bilateral patchy infiltration. He was treated with oral amoxicillin/clavulanic acid $(625 \mathrm{mg}$ q8 h, azithromycin (500 mg daily), hydroxychloroquine (400 mg BID), paracetamol (1000 mg TID), and subcutaneous enoxaparin ( $40 \mathrm{mg}$ once daily). The patient's fluorescence polymerase chain reaction result for SARS-CoV-2 returned positive. On the second day of admission, the

This article is part of the Topical Collection on COVID-19

Electronic supplementary material The online version of this article (https://doi.org/10.1007/s42399-020-00568-7) contains supplementary material, which is available to authorized users.

Hakam Alzaeem

Halzaeem@hamad.qa

1 Department of Cardiology and Cardiovascular Surgery, Hamad Medical Corporation (HMC), P.O Box 3050, Doha, Qatar

2 Qatar and Weill Cornell Medical College, Doha, Qatar

3 Critical Care and Pulmonary Medicine, HMC, Doha, Qatar patient's fever subsided and his overall symptoms improved. On admission day 5 , the patient became hypoxic with oxygen saturation of $<90 \%$ requiring supplemental oxygen inhalation initially with oxygen inhalation by non-rebreather mask at the rate of $81 / \mathrm{min}$, which was subsequently increased to $10 \mathrm{l} / \mathrm{min}$. On day 8 , the patient suddenly developed profound hypotension and had severe desaturation requiring urgent endotracheal intubation. While D-dimer remained normal until day 8 , the inflammatory parameters were progressively increasing (Table 1). Urgent bedside transthoracic echocardiography (TTE) revealed large transient thrombi in the right atrium (RA) and right ventricular (RV) with McConnell's sign and severe RV failure (see videos). Patient urgently received fibrinolytic therapy (alteplase $100 \mathrm{mg}$ ) without any significant improvement while preparations are underway for VAECMO; unfortunately the patient had cardiac arrest and subsequently passed away.

\section{Discussion}

Since December 2019, the COVID-19 outbreak has spread worldwide. Around $14 \%$ of cases are reported to have severe symptoms and 5\% of patients developed respiratory failure, shock, and multi-organ failure. A strong correlation of COVID-19 and hypercoagulopathy has been confirmed in ICU and non-ICU COVID-19 patients [1], particularly those with limited mobility and high levels of inflammatory markers [2]. Different mechanisms contributed to the pathogenesis of hypercoagulopathy in COVID-19 disease including stasis, 
Table 1 Lab results

\begin{tabular}{|c|c|c|c|c|c|c|}
\hline Laboratory test & Reference Values & Arrival & Hospital day 4 & Hospital day 5 & Hospital day 7 & Hospital day 8 \\
\hline $\mathrm{FiO} 2(\%)$ & 21 & & 21 & 80 & 80 & 91 \\
\hline $\mathrm{PaO} 2$ (mmHg) & $83-108$ & & 98 & 96 & 95 & 88 \\
\hline $\mathrm{PaO} 2$ to $\mathrm{FiO} 2$ ratio & $>400$ & & 466 & 120 & 118 & 96.7 \\
\hline $\mathrm{pH}$ & $7.35-7.45$ & & 7.45 & 7.46 & 7.47 & 6.94 \\
\hline $\mathrm{PaCO} 2$ & $35-45$ & & 32 & 33 & 33 & 66 \\
\hline Troponin T (ng/ml) & $(3-15)$ & & 15 & 12 & 16 & 28 \\
\hline NT-proBNP (pg/ml) & $<125$ & & 434 & & & \\
\hline C-reactive protein $(\mathrm{mg} / \mathrm{dL})$ & $0-5$ & 261.8 & 353.1 & 274.7 & 232.5 & 276.2 \\
\hline Ferritin (ng/ml) & $30-553$ & 907 & 1.328 & 1.653 & 1.746 & 1.909 \\
\hline LDH (U/L) & $135-225$ & & 482 & 380 & 441 & 509 \\
\hline White blood cells $(\times 109 / \mathrm{L})$ & $(4-10)$ & 10.4 & 18.7 & 17.1 & 16.7 & 17 \\
\hline AST (U/L) & $0-40$ & 31 & 56 & 41 & 32 & 2052 \\
\hline $\operatorname{ALT}(\mathrm{U} / \mathrm{L})$ & $0-41$ & 22 & 30 & 25 & 27 & 634 \\
\hline D-dimer & $0-0.49$ & 0.25 & 0.4 & 0.49 & 0.79 & 9.14 \\
\hline Fibrinogen & $2-4.1$ & & 6.5 & 6.6 & 8.1 & 7.8 \\
\hline APTT & $25.1-36.5$ & & 43.8 & 36.4 & 33.4 & 30.4 \\
\hline
\end{tabular}

endothelial injury, and coagulation abnormalities such as elevated D-dimer, fibrinogen, von Willebrand factor (VWF) antigen, and factor VIII activity [3]. A retrospective study showed that microvascular pulmonary thrombosis in patient with COVID-19 pneumonia was not influenced by preadmission treatment with anti-thrombotic therapy which may indicate a complex interplay between SARS-CoV-2 and clotting system activation [4].

Table 2 Reported case reports of pulmonary embolism in patients with COVID-19

\begin{tabular}{|c|c|c|c|c|c|c|c|}
\hline Author & Country & $\begin{array}{l}\text { Agel } \\
\text { gender }\end{array}$ & COVID-pneumonia & $\begin{array}{l}\text { Prophylactic } \\
\text { anticoagulants }\end{array}$ & Day of diagnosis & $\begin{array}{l}\text { Diagnostic } \\
\text { modality }\end{array}$ & Outcome \\
\hline Julien Poissy [3] & $\begin{array}{l}\text { France } \\
\text { Case-series }\end{array}$ & $\begin{array}{r}(29 \text { to } \\
80) \\
13 / M \\
9 / W\end{array}$ & Yes & $\begin{array}{l}20 \mathrm{Yes} \\
2 \mathrm{No}\end{array}$ & $?$ & $C T$ & $?$ \\
\hline Waqas Ullah [5] & $U S A$ & $59 / W$ & Yes & No & $\begin{array}{l}\text { Day before } \\
\text { discharge }\end{array}$ & $C T$ & Alive \\
\hline $\begin{array}{l}\text { Dany } \\
\quad \text { Jasinowodolinski } \\
{[6]}\end{array}$ & Brazil & $40 / M$ & Yes & No & 7 & $C T$ & $?$ \\
\hline $\begin{array}{l}\text { Gian Battista Danzi } \\
\text { [7] }\end{array}$ & Italy & $75 / W$ & Yes & No & 1 & $C T$ & $?$ \\
\hline D.C.Rotzinger $[8]$ & Switzerland & 75 & Yes & Yes & 4 & $C T$ & \\
\hline $\begin{array}{l}\text { Bruno Lima Moreira } \\
\text { [9] }\end{array}$ & Brazil & $52 / M$ & $\begin{array}{l}\text { Yes (Lupus anticoagulant } \\
\text { positive) }\end{array}$ & No & 2 & $C T$ & Alive \\
\hline $\begin{array}{l}\text { Adriana Tamburello } \\
\text { [10] }\end{array}$ & Switzerland & $50 / M$ & Yes & Yes & $?$ & $C T$ & $?$ \\
\hline Horowitz, J. M [11] & USA & $62 / M$ & Yes & Yes & 2 & $\begin{array}{l}\text { Echocardiography } \\
\text { TEE }\end{array}$ & Died \\
\hline Scott E Janus [12] & $U S A$ & $64 / M$ & Yes & Yes & 5 & $\begin{array}{l}\text { Echocardiography } \\
\text { TTE }\end{array}$ & Alive \\
\hline Current study & Qatar & $54 / M$ & Yes & Yes & 8 & $\begin{array}{l}\text { Echocardiography } \\
\text { TTE }\end{array}$ & Died \\
\hline
\end{tabular}

$W$ woman, $M$ man

TTE transthoracic echocardiography

TEE transesophageal echocardiography 
The first case of COVID-19 complicated by massive pulmonary embolism (PE) and RV failure was published in JACC April 2020 [5]. Later on, many cases were reported and vast majority of them were diagnosed using computerized tomography (Table 2).

To the best of our knowledge, our case is one the first few cases of COVID-19 complicated by pulmonary embolism diagnosed by echocardiography $[11,12]$. Transthoracic echocardiography is more convenient as it can be performed bedside immediately without the need to move the patient. Moreover, as far as we know, this case is one of the few cases that has developed fatal thromboembolism despite being on anticoagulants [13] and having normal D-dimer level on presentation until the day of event; this might suggest the need of higher doses of prophylactic anticoagulants in patients with severe COVID-19 pneumonia even with normal D-dimer.

\section{Conclusions}

Fatal thrombosis may develop in patients with severe COVID19 pneumonia despite prophylactic anticoagulation; therefore, more evidence is needed for identification of these high-risk patients and the proper doses of prophylactic anticoagulants.

\section{Learning Objectives}

- To stress on the potential role of transthoracic echocardiography as a quick and widely available tool to help in the diagnosis of pulmonary embolism in COVID-19 patients

- To question the proper dosage of prophylactic anticoagulation in COVID-19 patients

Funding Open Access funding provided by the Qatar National Library.

\section{Compliance with Ethical Standards}

Conflict of Interest None.

Ethical Approval Obtained from the institutional review board.

\section{Informed Consent Obtained.}

Open Access This article is licensed under a Creative Commons Attribution 4.0 International License, which permits use, sharing, adaptation, distribution and reproduction in any medium or format, as long as you give appropriate credit to the original author(s) and the source, provide a link to the Creative Commons licence, and indicate if changes were made. The images or other third party material in this article are included in the article's Creative Commons licence, unless indicated otherwise in a credit line to the material. If material is not included in the article's Creative Commons licence and your intended use is not permitted by statutory regulation or exceeds the permitted use, you will need to obtain permission directly from the copyright holder. To view a copy of this licence, visit http://creativecommons.org/licenses/by/4.0/.

\section{References}

1. Klok FA, Kruip, et al. Incidence of thrombotic complications in critically ill ICU patients with COVID-19. Thromb Res. 2020;191:145-7. https://doi.org/10.1016/j.thromres.2020.04.013.

2. Lodigiani C, Iapichino, Humanitas COVID-19 Task Force, et al. Venous and arterial thromboembolic complications in COVID-19 patients admitted to an academic hospital in Milan, Italy. Thromb Res. 2020;191:9-14. https://doi.org/10.1016/j.thromres.2020.04. 024.

3. Poissy J, Goutay J, Caplan M, Parmentier E, Duburcq T, Lassalle F, et al. Pulmonary embolism in COVID-19 patients: awareness of an increased prevalence. Circulation. 2020. https://doi.org/10.1161/ CIRCULATIONAHA.120.047430 Advance online publication.

4. Russo V, Di Maio M, Attena E, Silverio A, Scudiero F, Celentani $\mathrm{D}$, et al. Clinical impact of pre-admission antithrombotic therapy in hospitalized patients with COVID-19: a multicenter observational study. Pharmacol Res. 2020;159:104965. Advance online publication. https://doi.org/10.1016/j.phrs.2020.104965.

5. Ullah W, Saeed R, Sarwar U, Patel R, Fischman DL. COVID-19 complicated by acute pulmonary embolism and right-sided heart failure. JACC Case Rep. 2020. https://doi.org/10.1016/j.jaccas. 2020.04.008 Advance online publication.

6. Jasinowodolinski D, Filisbino MM, Baldi BG. COVID-19 pneumonia: a risk factor for pulmonary thromboembolism? J Bras Pneumol. 2020;46(4):e20200168. https://doi.org/10.36416/18063756/e20200168.

7. Danzi GB, Loffi M, Galeazzi G, Gherbesi E. Acute pulmonary embolism and COVID-19 pneumonia: a random association? Eur Heart J. 2020;41(19):1858. https://doi.org/10.1093/eurheartj/ ehaa 254.

8. Rotzinger DC, Beigelman-Aubry C, von Garnier C, Qanadli SD. Pulmonary embolism in patients with COVID-19: time to change the paradigm of computed tomography. Thromb Res. 2020;190: 58-9. https://doi.org/10.1016/j.thromres.2020.04.011.

9. Moreira BL, Santana P, Zanetti G, Marchiori E. COVID-19 and acute pulmonary embolism: what should be considered to indicate a computed tomography pulmonary angiography scan? Rev Soc Bras Med Trop. 2020;53:e20200267. https://doi.org/10.1590/00378682-0267-2020.

10. Tamburello A, Bruno G, Marando M. COVID-19 and pulmonary embolism: not a coincidence. Eur J Case Rep Intern Med. 2020;7(6):001692. https://doi.org/10.12890/2020 001692.

11. Janus SE, Hajjari J, Cunningham MJ, Hoit BD. COVID19: a case report of thrombus in transit. Eur Heart J Case Rep:ytaa189. https:// doi.org/10.1093/ehjcr/ytaa189.

12. Horowitz JM, Yuriditsky E, Henderson IJ, Stachel MW, Kwok B, Saric M. Clot in transit on transesophageal echocardiography in a prone patient with COVID-19 acute respiratory distress syndrome. CASE (Philadelphia, Pa.). 2020. https://doi.org/10.1016/j.case. 2020.05.007 Advance online publication.

13. Di Tano G, Moschini L, Loffi M, Testa S, Danzi GB. Late pulmonary embolism after COVID-19 pneumonia despite adequate rivaroxaban treatment. Eur J Case Rep Intern Med. 2020;7(7): 001790. https://doi.org/10.12890/2020_001790.

Publisher's Note Springer Nature remains neutral with regard to jurisdictional claims in published maps and institutional affiliations. 